\title{
NECROBIOTIC NODULES OF RHEUMATOID ARTHRITIS TYPE WITH LIPOID DEPOSITION
}

\author{
BY
}

\section{ERNEST FLETCHER}

The incidence and structure of subcutaneous nodules in rheumatic fever and rheumatoid arthritis have been the subject of research for many years. In 1937 Collins published a paper on the subcutaneous nodule in rheumatoid arthritis, and in 1939 he reviewed in these Annals some of the work on the pathology of rheumatic fever and rheumatoid arthritis. He mentions the basic pattern of tissue change as coming under four heads-exudation, mesenchymal proliferation, connective tissue degeneration, and leucocytic infiltration. He remarks that this general pattern is an elementary one and cannot be regarded as specific, but that generally speaking it makes up a histological picture characteristic of rheumatism. To the connective tissue degeneration the name of " fibrinoid" degeneration has been given. This change is also part of the Arthus phenomenon, and is regarded as a basic type of tissue reaction in states of hypersensitivity. He also mentions the vascular lesions commonly found in rheumatic fever but only in the joints and subcutaneous nodules in arthritis.

It seems now to be generally agreed that the typical subcutaneous nodules of rheumatoid arthritis all have a similar structure. This structure consists generally of a central area of fibrinoid degeneration and necrosis, surrounded by a cellular band, the most noticeable feature of this surround being a palisade arrangement of fibroblasts. The case to be described in this article falls only partly into this category, and it should be mentioned that Parkes Weber published a somewhat similar case, though differing in several features, in the Annals of 1944.

\section{Case Notes}

A.C. Male. Aet 42.-The illness started suddenly. in January 1938, with pain in the right shoulder which came on during the night. The following week pain developed in the hands when he was at the seaside on holiday. He was treated for five months with French iodine, but without relief, and in May 1938 was diagnosed as suffering from infective arthritis and treated with Sanocrysin. During the following year he made some progress but was off work for six months, partly because of an attack of pneumonia and pleurisy in May 1939. In February 1941 he received T.A.B. injections. Later in 1941 he had another attack of pneumonia, and after this the arthritic condition became much worse, so that in March 1942 both olecranon bursae were enlarged to the size of a walnut.*

Biopsy was performed on Feb. 16, 1942. The report read: "Chronic inflammation of bursa. There is much organizing fibrin within the sac. Numerous histiocytes with few leucocytes present. There is nothing suggesting gout, but it well might be rheumatoid arthritis." His temperature never rose above $99.2^{\circ} \mathrm{F}$., and the sedimentation rate at that time was $42 \mathrm{~mm}$. at the hour (Westergren). He was given a total of $0.87 \mathrm{mg}$. sodium aurothiomalate and advised to attend the Red Cross Clinic, Peto Place, London, where I saw him in June 1942.

All the small joints were involved, the hands showing a fair degree of deformity, with ulnar deviation. There was a synovial effusion in the right knee, and limitation of movement in the shoulders, left knee, and both ankles. Both feet were stiff, and there was tenderness over the metatarso-phalangeal joints. The weight was $8 \mathrm{st} .7 \mathrm{lb}$. At the beginning of his illness in 1938 it was said to have been $10 \mathrm{st} .13 \mathrm{lb}$. $X$ ray examination showed the changes of infective arthritis, and the blood sedimentation rate was 40 . About this time he developed a chronic antritis, which was operated on two months later. The operation was followed by a general flare-up in all the joints, but the blood sedimentation rate-which had risen-fell from $60 \mathrm{~mm}$. at the hour to 41 .

Nodules first made their appearance in July 1942. The blood count at this time was: haemoglobin $81 \%$, red cells $4,700,000$ per c.mm., colour index $0 \cdot 86$, white cells 5,300 per c.mm.

At the end of 1942 he was transferred to a sector hospital, and here the haemoglobin rose to $95 \%$, the white cells remained stationary at 5,900 per c.mm., and the sedimentation rate fell to $18 \mathrm{~mm}$. at one hour. The blood uric acid was $3 \mathrm{mg}$. per $100 \mathrm{c.cm}$. of blood; the gonococcal fixation test was negative, as were urethral smears for gonococci. Two months later, after removal of his tonsils, he went to a spa for treatment. The blood sedimentation rate was 44 .

On examination in January 1944 he was found to be in very poor condition and losing weight. The

* I am indebted to Prof. G. W. Pickering for the history of what occurred at this time and to Prof. W. D. Newcomb for the pathological report. 


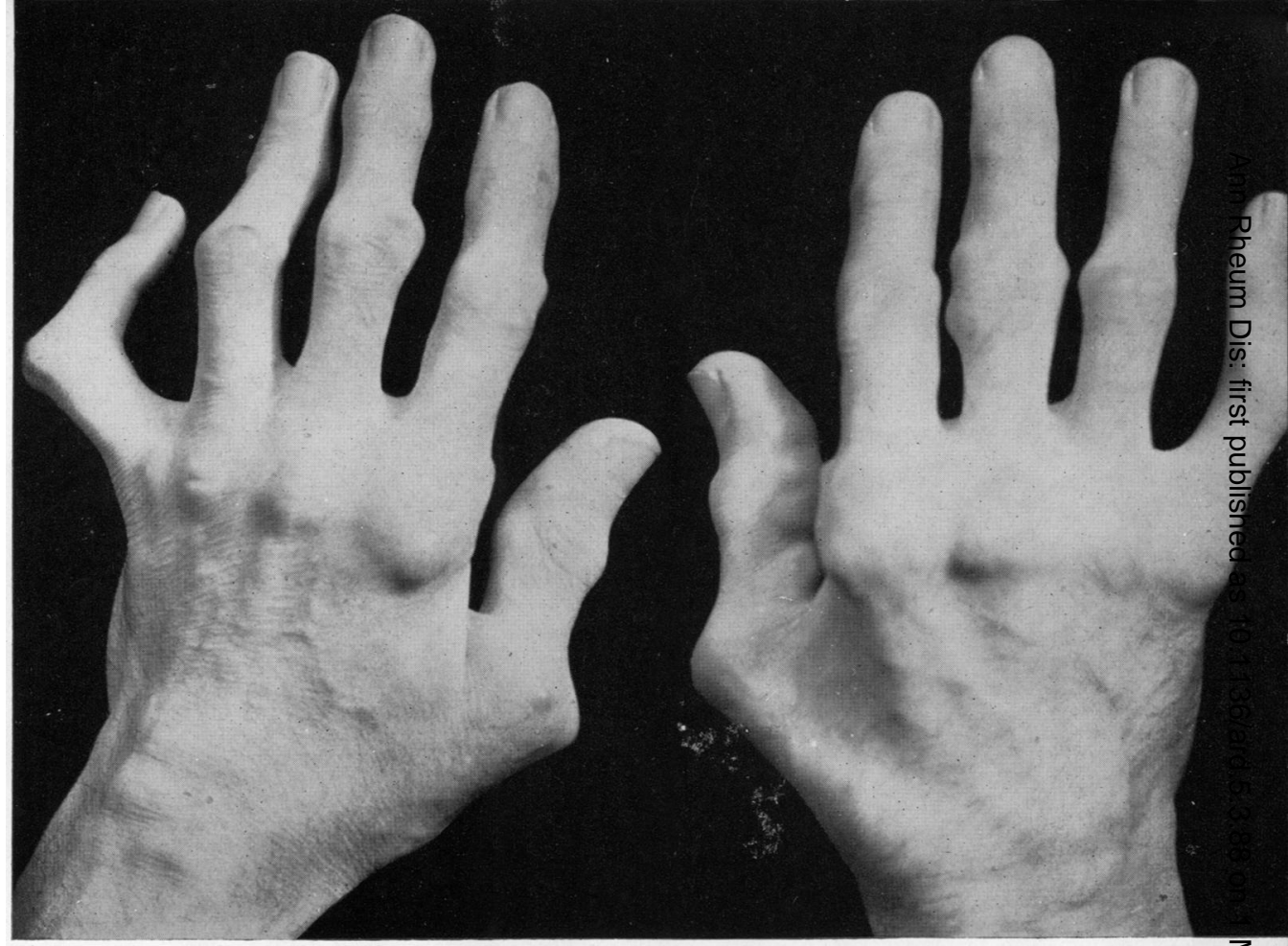

Fig. 1.-Patient's hands, showing the nodules.

임

FIG. 2.-Showing the typical radiological change of rheumatoid arthritis in the hands.

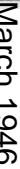

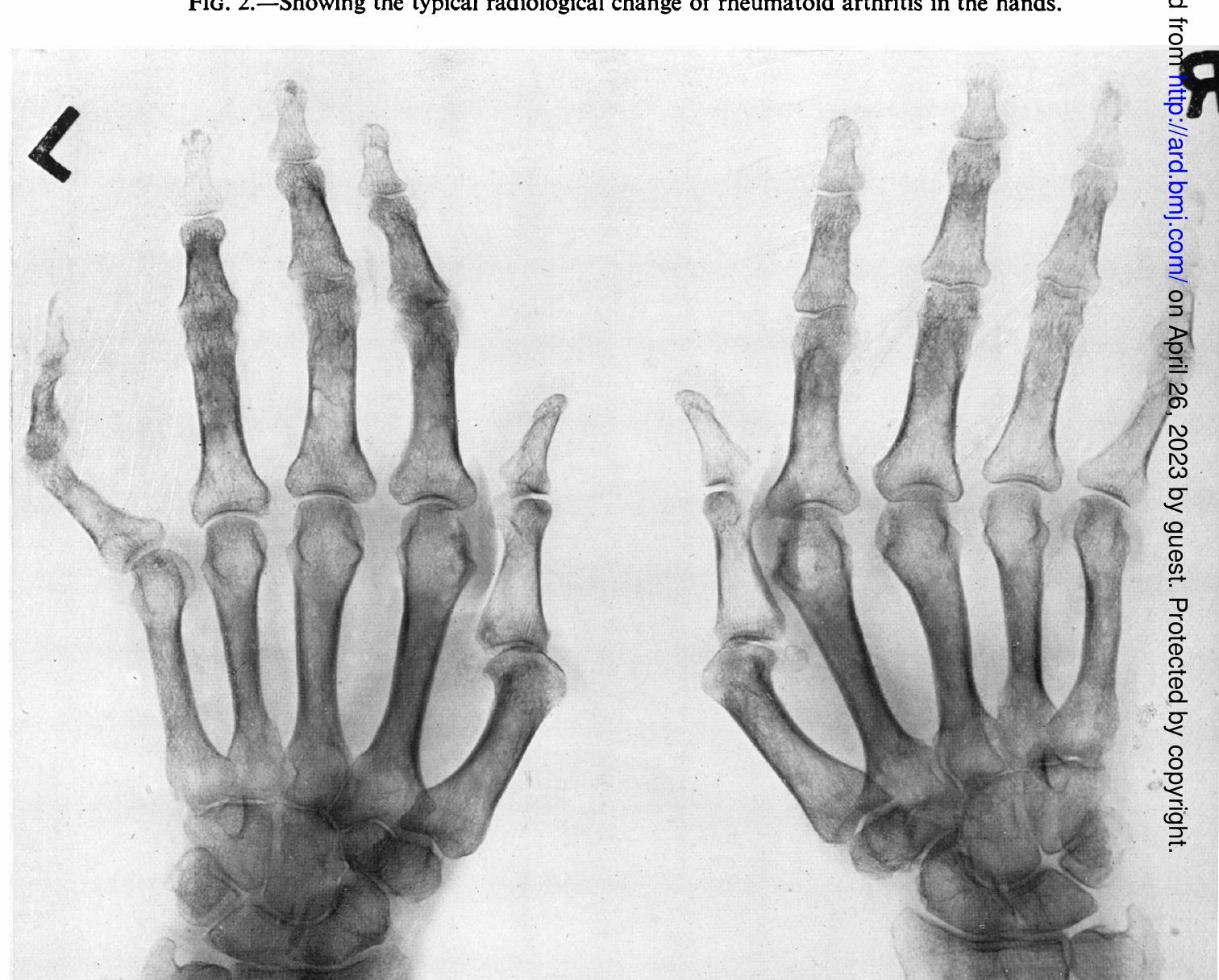




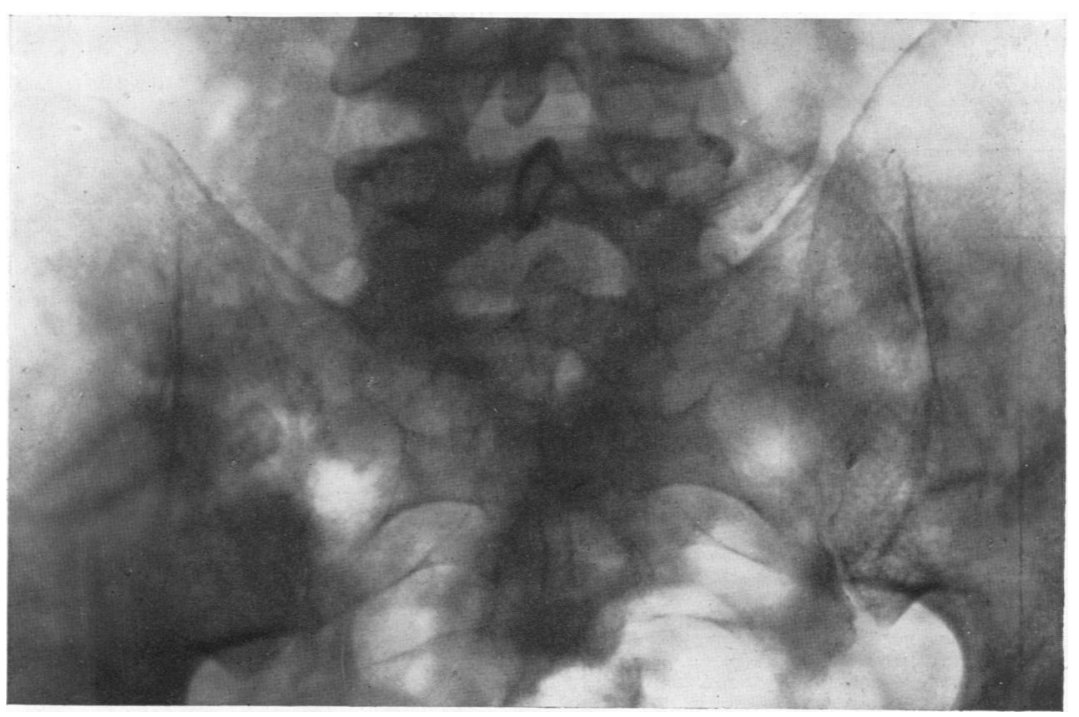

heart and lungs were apparently normal, blood pressure $105 / 80 \mathrm{~mm}$. $\mathrm{Hg}$. He was then edentulous, tongue clean, fauces clear. There was limitation of movement in all joints except those of the spine. The hands were much deformed, with ulnar deviation and contracture of the fifth finger. Nodules were present in many places. In addition, both olecranon bursae were much thickened and swollen.

\section{Site OF THE Nodules}

In May the exact size and position of the nodules was as follows:

Head.-Bilaterally symmetrical nodules, $\frac{1}{4}$ in. diameter over upper parts occipital bones attached to periosteum. Fibrous consistency. No other nodules on cranial bones.

Neck.-A few small discreet glands palpable.

Chest.-Anterior: no nodules. Posterior: spines of both scapulae showed nodules. Right scapula, nodule $\frac{1}{2} \times 1$ in. at lateral end of spine, deeply attached, fairly hard. Two smaller nodules, medially similar in consistency and attachments. Left scapula, nodules similarly situated, but slightly bigger.

Abdomen-Anterior: about six inguinal glands palpable on each side. Firm and mobile. The largest was about the size of a walnut. Posterior: irregular nodules of similar character over both posterior, inferior iliac spines. Irregular nodule over sacro-coccygeal junction.

Upper arms.-Three to four firm glands palpable in both axillae. Right: enlarged olecranon bursa with small hard nodules. Small nodules over first condyle of humerus, and one nodule, $\frac{1}{4}$ in. in diameter, over upper third posterior part of ulnar. Left: according to patient, similar nodules were removed as on right side. Two (?) glands were palpable in the left epitrochlear region.

Forearms.-Numerous small nodules over lower ends of both radii and ulnae.

Wrists and hands.-Bilateral ulnar deviation. Nodules of various sizes were visible and palpable in all metacarpophalangeal and interphalangeal joints. They were for the most part superficial, but some appeared attached to the bone. There were also some small nodules in the tendons on the back of the hands.

Legs.-Thighs: over both greater trochanters, irregular nodules were palpable and deeply attached. Knees: some small nodules palpable over the anterior surfaces of both patella. There was erythema over these nodules. Feet and ankles: fibular deviation of toes. The only nodules palpable were over both first metatarsophalangeal joints. The other metatarsophalangeal and interphalangeal joints were slightly swollen in varying degrees, but no other nodules were palpable.

(See Figs. 1 to 6.)

Biopsies were made on Feb. 12, 1944. Drs. George Graham and Parkes Weber saw the patient at the Royal Free Hospital in May, and on their suggestion further biopsies were made in June. During the patient's stay in hospital his temperature rose to $100^{\circ} \mathrm{F}$. on two occasions; the highest pulse rate was 80 per minute. The blood chemistry was

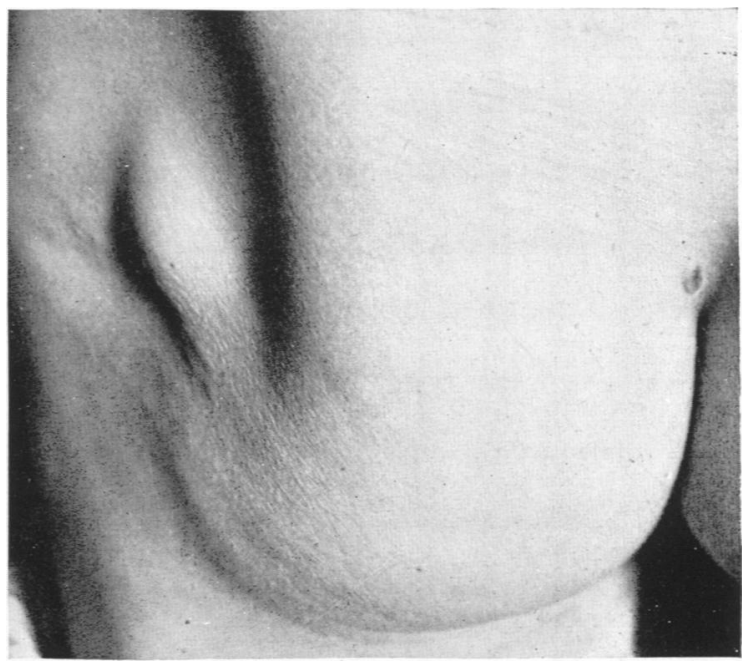

Fig. 6.-Note nodule in the buttock, and the muscle wasting. 
investigated by Miss Lucy Wills and the histology by Dr. Lowenberg. For the sake of convenience, the blood findings are tabulated with Dr. Parkes Weber's case.

\begin{tabular}{|c|c|c|}
\hline & $\begin{array}{c}\text { Dr. Parkes Weber's } \\
\text { case }\end{array}$ & This case \\
\hline $\begin{array}{l}\text { Urine } \\
\text { Fasting blood sugar } \\
\text { Sugar tolerance test } \\
\text { Blood cholesterol .. }\end{array}$ & $\begin{array}{l}\text { Normal. } \\
0.07 \% \text {. } \\
\text { Normal. } \\
\text { (1) } 230 \mathrm{mg} \text {. per } 100 \\
\text { c.cm. } \\
\text { (2) } 350 \mathrm{mg} \text {. per } 100 \\
\text { c.cm. } \\
\text { After treatment fell } \\
\text { to } 110 \mathrm{mg} \text {. per } 100 \\
\text { c.cm. }\end{array}$ & $\begin{array}{l}\text { Normal. } \\
0 \cdot 103 \% \text {. } \\
\text { Normal. } \\
\text { (1) } 135 \mathrm{mg} \text {. per } 100 \\
\text { c.cm. } \\
\text { (2) } 154 \mathrm{mg} \text {. per } 100 \\
\text { c.cm. }\end{array}$ \\
\hline Histamine test meal & $\begin{array}{l}\text { Complete absence of } \\
\text { acid. }\end{array}$ & $\begin{array}{l}\text { Complete absence of } \\
\text { acid. }\end{array}$ \\
\hline $\begin{array}{l}\text { Van den Bergh test.. } \\
\text { Wassermann reaction }\end{array}$ & $\begin{array}{l}\text { Positive indirect. } \\
\text { Negative. }\end{array}$ & $\begin{array}{l}\text { Positive indirect. } \\
\text { Slight reaction. } \\
\text { Kahn negative. }\end{array}$ \\
\hline $\begin{array}{l}\text { Blood sedimentation } \\
\text { rate. }\end{array}$ & Normal. & $\begin{array}{l}\text { Varied from } 70-30 \\
\text { mm. at the hr. } \\
\text { (Westergren). }\end{array}$ \\
\hline $\begin{array}{l}\text { Blood urea . . } \\
\text { Blood uric acid } \\
\text { Non-protein nitrogen } \\
\text { Serum calcium } \\
\text { Blood count: }\end{array}$ & $\begin{array}{l}36.5 \mathrm{mg} \text {. per } 100 \mathrm{c} . \mathrm{cm} \text {. } \\
3.70 \mathrm{mg} \text {. per } 100 \mathrm{c.cm} \text {. } \\
30.5 \mathrm{mg} \text {. per } 100 \mathrm{c.cm} \text {. } \\
8.5 \mathrm{mg} \text {. per } 100 \mathrm{c.cm} .\end{array}$ & $\begin{array}{l}34 \mathrm{mg} \text {. per } 100 \mathrm{c.cm} \text {. } \\
2.70 \mathrm{mg} \text {. per } 100 \mathrm{c.cm} \text {. } \\
32 \mathrm{mg} \text {. per } 100 \mathrm{c.cm} \text {. } \\
10.1 \mathrm{mg} \text {. per } 100 \mathrm{c.cm}\end{array}$ \\
\hline $\begin{array}{l}\text { Haemoglobin } \\
\text { Red blood count.. } \\
\text { White blood count } \\
\text { Eosinophils }\end{array}$ & $\begin{array}{l}84 \% . \\
\text { Normal. } \\
3,500 \text { per c.mm. } \\
7 \% .\end{array}$ & $\begin{array}{l}79 \% \\
4,305,000 \text { per c.mm. } \\
6,675 \text { per c.mm. } \\
5 \%\end{array}$ \\
\hline
\end{tabular}

\section{Clinical and Biochemical comparison with Dr. Parkes Weber's Case}

In the present case the nodules developed $4 \frac{1}{2}$ years after the development of the arthritic symptoms; in Dr. Weber's case both developed simultaneously. His nodules were reddish, but in this case pale. There was only one marked difference in the site of the nodules, for in the case described in this article the face and ears were spared entirely. The olecranon bursae were markedly affected in both cases. The nodules were not symmetrically disposed. Slight fever and loss of weight were present in both cases. In the findings set out in the table the only abnormalities in both cases are complete absence of acid in the histamine test meal, and a slight eosinophilia. In Dr. Weber's case a high blood cholesterol was found on one occasion. In the case now described the blood sedimentation rate was consistently raised at various levels, but not in Dr. Weber's.

In addition to these two cases, Dr. George Graham has shown one somewhat similar. His patient died of a sarcoma.

\section{Report by Dr. Lowenberg}

The material examined consisted of four subcutaneous nodules from the forearm, olecranon bursa, and the tissues over the metacarpal-phalangeal joint. Histological examination showed that the most striking feature of all the nodules is a widespread necrosis (Fig. 7). The necrotic areas in the haematoxylin-eosin preparations stain a dull red colour and may contain nuclear or cell debris, the

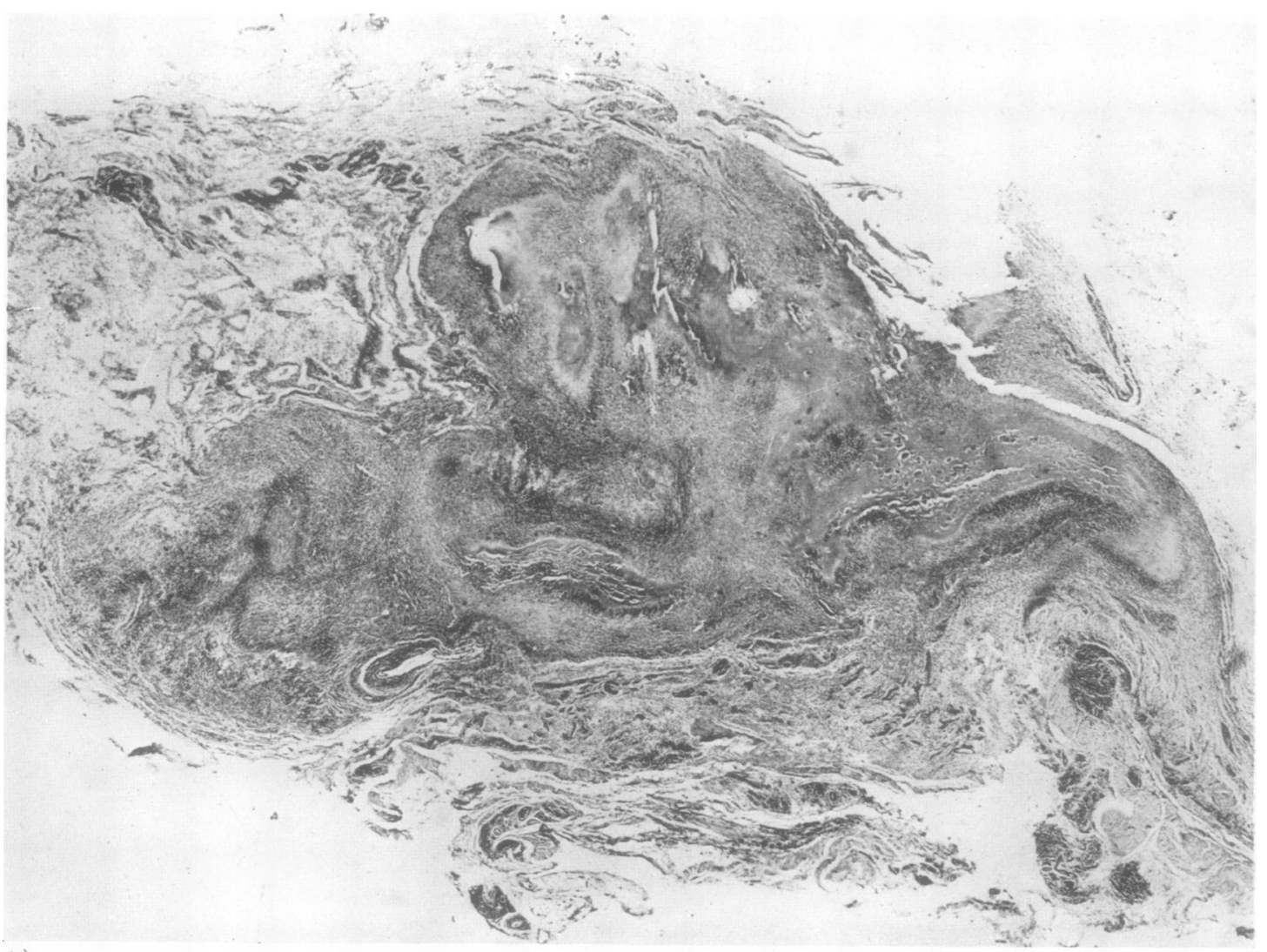

FIG. 7.-Dr. Lowenberg's report-microphotograph $\times 18$. Showing an entire nodule. Note areas of necrosis with fibroblastic reaction and the well-defined edge of the whole nodule. 


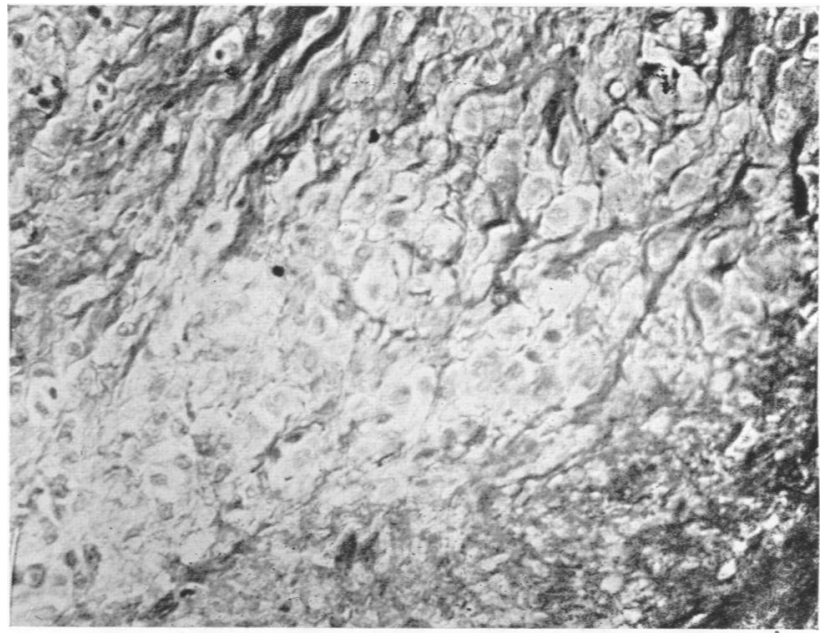

FIG. 8.-Dr. Lowenberg's report-microphotograph $\times 100$. The bottom portion shows the necrotic area with a band of "foam" cells above it. The top section includes the collagen fibrils with part of the fibroblastic reaction.

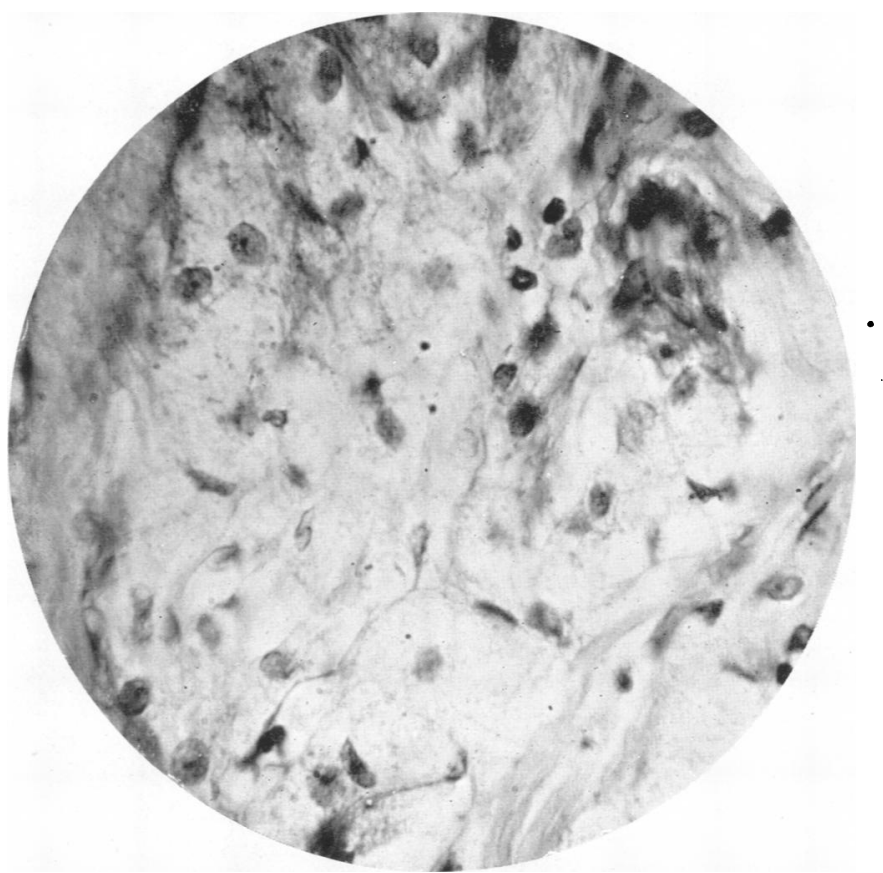

FIG. 9.-Dr. Lowenberg's report-microphotograph $\times 1,000$. Shows at the top, right, a foreign body giant cell. The centre portion shows foam cells with vacuoles.

remains of interlacing tissue bundles, or more frequently regularly dispersed, brightly staining bodies of different sizes, which are probably hyaline material. The necrotic areas, which are on the whole sharply limited, are frequently connected with other necrotic foci, but isolated areas also occur. The outermost zone of any one necrotic area is a small band of waxy appearance which does not stain as deeply as the central zone; surrounding this zone is another more or less broad band con- sisting of closely-packed cells (cellular band) which passes into a zone of interlacing connective tissue bundles. The nature of the cellular band varies from nodule to nodule, probably depending on the stage of development of each individual nodule. Around most of the necrotic areas there is a broad band composed of typical foam cells lying among scanty connective tissue bundles (Figs. 8 and 9). These cells are large, pale, oval, or round cells, whose cytoplasm shows numerous very distinct 


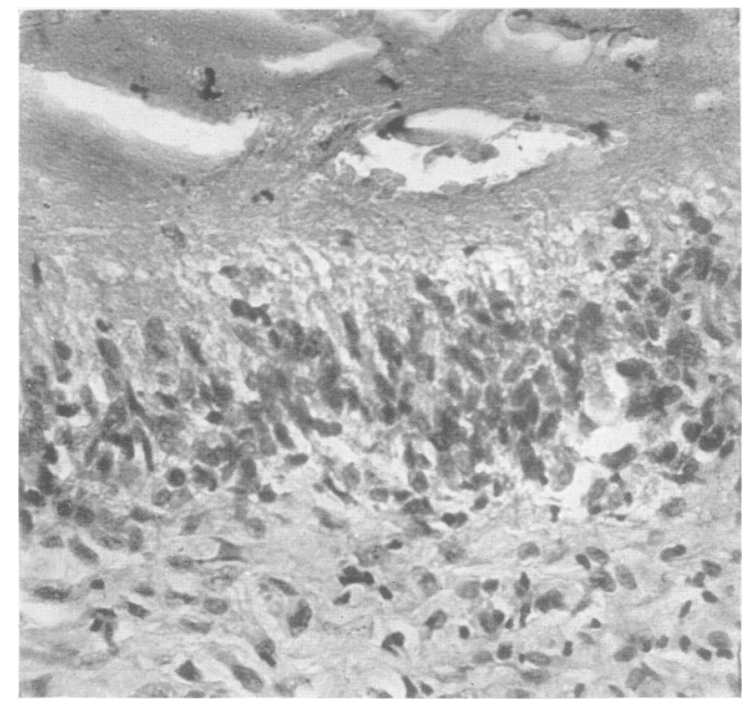

FIG. 10.-Dr. Lowenberg's report-microphotograph $\times 100$. Showing the palisade arrangement of fibroblasts.

vacuoles. Many of these cells are very large, and some are mis-shapen and swollen, with poorlystained cytoplasm; in some cases the cell membrane alone indicates the pre-existent cells. Multinucleated and giant cells of foreign-body type are frequent, but no foreign-body cells of Touton type have been identified. These foam cells gave a positive Schultze test for cholesterol, and showed fine orange-red stained droplets in sections stained with Sudan. The connective tissue is scanty, with empty spaces between the connective tissue bundles; these spaces are filled with orange-red stained material in sections stained with Sudan. There are no inflammatory cells in this zone.

In another nodule the cellular band differs markedly from that described above. It is composed of a zone of radially arranged fibroblasts (Fig. 10) which pass into the surrounding zone of connective tissue bundles. The zone immediately beyond the "cellular" band is less cellular, and consists largely of interlacing connective tissue bundles which show signs of degeneration-the most striking sign being the numerous enlarged empty spaces between the interlacing bundles. There are also numerous foam cells which are often more distinct than those immediately surrounding the necrotic area; giant and multinucleated cells are also present, but there are very many more connective tissue cells and numerous inflammatory cells. The inflammatory cells include round cells, plasma cells, mast cells, and sometimes numerous eosinophils. There are numerous dilated and well-filled arterioles and capillaries. The transition to the connective tissue which circumscribes the nodules is gradual; but, though there is no capsule, the nodular formation is perfectly definite. In this outer zone the changes in the capillaries and smaller vessels are insignificant, but the larger vessels show more striking changes; their walls are considerably thickened and often contain foam cells, while the intima is swollen, sometimes to the point of occlusion. A perivascular cellular infiltration is often present. Well-developed foam cells can be seen occasionally in the lumen of certain vessels which may be situated some distance from the necrotic areas, or even, in some cases, from the nodules themselves.

All four nodules examined show the same general structure, but the nodule from the bursa olecrani shows the largest necrosis and the most marked degenerative changes in connective and elastic tissue.

\section{Examination for Cholesterol and Other Lipoids}

In the nodules from the bursa olecrani and from the finger, cholesterol was demonstrated by the Schultze test in the greater part of the necrosis and the immediate surrounding tissues. Further from the necrosis the test was less definite, and in the periphery of the nodule there was no cholesterol. In one subcutaneous nodule the Schultze test showed cholesterol only very faintly in a few areas. By staining with Sudan, all the parts with the positive Schultze test showed an orange-red colour. Where the Sudan staining was not too intense, orange-red stained masses could be seen filling the spaces noted between the connective tissue bundles, and fine granules filling the cells.

\section{Summary}

There is present in all four specimens a deep subcutaneous nodule formation with an area of complete necrosis in the centre of the nodules, which, in three of the specimens, is surrounded by a cellular band containing numerous foam cells and many multinucleated and foreign-body giant cells. Surrounding this again is a partly degenerated connective tissue band which contains, in addition to welldefined foam cells, numerous inflammatory cells. 
In the other nodule the cellular zone is composed of fibroblasts arranged in a palisade manner. The vessels in the nodules and in the neighbourhood show endo-, meso-, and peri-arteritis. The necrotic areas and the surrounding tissues show the presence of cholesterol, situated both intra- and extracellularly.

\section{Differential Diagnosis}

The histological findings must be considered diagnostically in connexion with the clinical and other laboratory findings. The whole picture most nearly resembles the necrobiotic nodules of rheumatoid arthritis type with lipoid infiltration, though the histological picture differs in detail from the cases described by Parkes Weber (1944); for example, the palisade arrangement of the fibroblasts round the central necrotic areas is not always seen, and foam cells and giant cells are present. The foam cells differ in detail from those described by Freudenthal as "pre-xanthoma cells"; but the general picture, combined with the clinical findings, make the diagnosis clear. Xanthoma tuberosum and necrobiosis lipoidica are excluded-the former by the deep subcutaneous nodule formation and the large necrotic areas with no sign of healing, and the latter by the deep position, the completely circumscribed necrosis and abundant intracellular cholesterol, and the numerous foam cells.

\section{Comment}

A case of rheumatoid arthritis is described. It is compared with one published by Parkes Weber, and mention is made of a third case, which was shown at the Royal Society of Medicine by Dr. George Graham. The only other reference in the literature is a paper by Layani which describes a condition possibly similar.

The points made by Dr. Lowenberg seem to show that the sections from this case differ in several important features from the necrobiotic nodules of rheumatoid arthritis described by Collins (1937).
However, the basic histological reaction of focal necrosis, fibroblastic proliferation, round-celled infiltration, and vessel damage are all present; and the dissimilarity is largely that of altered cytology.

Collins does not describe foam cells, nor giant cells of the foreign-body type as in this case; neither is the palisade fibroblastic barrier so marked in these specimens as in his The pathological picture is more akin to that of the case described by Parkes Weber and Freudenthal (1936) and by Parkes Weber (1944), under the title of " nodular nondiabetic cutaneous xanthomatosis with hypercholesterolaemia"; this case was also one of rheumatoid arthritis. Here certain cells were described as "pre-xanthoma cells," and it was suggested that with time they might develop into typical foam cells. This, however, was mere hypothesis, and it is possible that the cells were in the adult stage and that their appearance was due to some unusual lipoid that they contained.

Cells in the case discussed in the present paper showed vacuoles, cholesterol by the Schultze test, and apparently a more decisive staining with Sudan 3. The microscopic appearance is not dissimilar from the "pre-xanthoma" cells of Parkes Weber's case. Thus the possibility that the foam cells of this case represent the adult form of his "pre-xanthoma" cells cannot be ruled out. The question of the blood cholesterol level is of some interest, as it was low in this case and originally high in Parkes Weber's case. However, the deposition of cholesterol in the absence of a high blood cholesterol level is well known. Probably the best description of these apparently unique nodules would be "necrobiotic nodules of the rheumatoid arthritis type with lipoid deposition," as suggested by Dr. Lowenberg.

\section{REFERENCES}

Collins, D. H. (1937). J. Path. Bact., 45, 97. (1939). The Rheumatic Diseases, 1, 38

Layani, F. (1939). Bull. Soc. Med. Hop., Paris, 3rd Series, 55, 343. Weber, F. Parkes, and Freudenthal, W. (1937). Proc. Roy. Soc. Med., 30, 522. (1944). Annals of the Rheumatic Diseases, 4, 3. 